OPEN ACCESS

Edited by:

Michael Kogut,

Agricultural Research Service,

United States Department of

Agriculture, United States

Reviewed by:

Metzler-Zebeli Barbara,

University of Veterinary Medicine

Vienna, Austria

Leon Broom,

University of Leeds, United Kingdom

*Correspondence: Nicole C. Burdick Sanchez Nicole.Sanchez@usda.gov

${ }^{\dagger}$ Present Address: Todd R. Callaway,

Department of Animal and Dairy Science, University of Georgia, Athens, GA, United States

Specialty section: This article was submitted to Veterinary Infectious Diseases,

a section of the journal

Frontiers in Veterinary Science

Received: 16 November 2018 Accepted: 08 July 2019

Published: 24 July 2019

Citation:

Burdick Sanchez NC, Carroll JA, Corley JR, Broadway PR and Callaway TR (2019) Changes in the

Hematological Variables in Pigs Supplemented With Yeast Cell Wall in Response to a Salmonella Challenge in Weaned Pigs.

Front. Vet. Sci. 6:246 doi: 10.3389/fvets.2019.00246

\section{Changes in the Hematological Variables in Pigs Supplemented With Yeast Cell Wall in Response to a Salmonella Challenge in Weaned Pigs}

\author{
Nicole C. Burdick Sanchez ${ }^{1 *}$, Jeffery A. Carroll ${ }^{1}$, Jimmie R. Corley ${ }^{2}$, Paul R. Broadway ${ }^{1}$ \\ and Todd R. Callaway ${ }^{3+}$ \\ 1 USDA, ARS, Livestock Issues Research Unit, Lubbock, TX, United States, ${ }^{2}$ Phileo-Lesaffre Animal Care, Milwaukee, WI, \\ United States, ${ }^{3}$ USDA, ARS, Food and Feed Safety Research Unit, College Station, TX, United States
}

Stressors experienced by pigs at weaning may negatively impact health and productivity. Thus, supplements that enhance pig immunity during the early post-weaned period are of great interest to the swine industry. The objective of this experiment was to evaluate the performance and hematological responses of weaned pigs supplemented with yeast cell wall (YCW) when challenged orally with Salmonella Typhimurium. Weaned pigs were assigned to one of three treatments for $22 \mathrm{~d}$ ( $n=13 /$ treatment): Control diet, which was a non-medicated starter diet (Control); Control diet supplemented with YCW at 250 mg/kg BW (YCW250; Phileo Lesaffre Animal Care, Milwaukee, Wisconsin, USA); and Control diet supplemented with YCW at 500 mg/kg BW (YCW500). On d19 blood samples were collected from -6 to $72 \mathrm{~h}$ relative to oral Salmonella Typhimurium $\left(1 \times 10^{6} \mathrm{cfu} / \mathrm{pig}\right)$ challenge. Gain:feed was greater $(P=0.01)$ in YCW250 treatment compared to both Control and YCW500 pigs. Baseline intraperitoneal temperature was greater $(P<0.001)$ in YCW250 pigs than Control or YCW500 pigs. There was a treatment $x$ time interaction for the change in intraperitoneal temperature $(P<0.01)$, post-challenge cortisol, white blood cell counts $(\mathrm{WBC})$, neutrophils, and neutrophil:Iymphocyte ratio $(P \leq 0.03)$. Control pigs had greater $(P<0.05)$ cortisol concentrations than both $\mathrm{YCW}$-supplemented groups at $\mathrm{Oh}$, but Control pigs had reduced $(P<0.05)$ cortisol compared to YCW500 pigs at 24 and $30 \mathrm{~h}$ post-challenge. Control pigs had greater $(P<0.05)$ WBC counts than both YCW-supplemented groups 6 and $12 \mathrm{~h}$ post-challenge, and YCW250 pigs had reduced $(P<0.01)$ WBC counts than Control and YCW500 pigs $18 \mathrm{~h}$ post-challenge. Neutrophil counts were greater $(P<0.05)$ in Control pigs than both YCW-supplemented groups at 6 and $12 \mathrm{~h}$ post-challenge and were greater $(P=0.02)$ than YCW250 pigs at $18 \mathrm{~h}$ post-challenge. Lymphocytes were greater $(P<0.001)$ in Control and YCW500 pigs pre- and post-challenge compared to YCW250 pigs. Control pigs had the greatest $(P<0.001)$ monocyte counts compared to YCW treatments. There was no effect of yeast supplementation on fecal shedding or 
Salmonella counts in the rectum, colon or cecum $(P \geq 0.05)$. While some differences were observed in intraperitoneal temperature and some hematological variables, data suggests there were minimal effects of yeast supplementation on the acute immune response to Salmonella challenge.

Keywords: hematology, metabolism, pig, Salmonella, yeast cell wall

\section{INTRODUCTION}

One of the most difficult time periods in swine production with regards to animal health is weaning, due to weaning stress, as well as the declining supply of maternal antibodies which can result in immunosuppression (1). Furthermore, swine production over the past three decades has focused on increasing lean muscle deposition, which has resulted in a decline in energy available for optimal function of the immune system, leaving pigs more susceptible to disease $(2,3)$. The subsequent increase in disease incidence following weaning further decreases growth, reducing the growth potential of pigs throughout the post-weaning period (4). Therefore, the nursery stage in swine is a critical area in which improvements need to be made to enhance the health and well-being of pigs.

Further complicating the management of swine health is the increased consumer pressure to produce a more natural product. Increased regulations on the use of antimicrobials, such as the Veterinary Feed Directive, add to the pressure, and have stimulated producers to find alternative management strategies that improve animal health while maintaining productivity. Feed additives offer many advantages, are easily incorporated into swine management procedures, and there are a large variety of products available to producers that claim to improve animal health. Live yeast and yeast cell wall products have the potential to enhance the acute phase response to various immune challenges (5-7). Recent studies in cattle have found variations in the immune and metabolic responses between live yeast and yeast cell wall, and also between different strains and products (8-11). Additionally, Collier et al. (12) found that supplementation of young pigs with Saccharomyces cerevisiae spp. boulardii enhanced average daily gain (ADG), reduced endotoxin-induced mortality and increased total white blood cell counts. The difference in circulating white blood cells is interesting and suggests a change in the inflammatory status of the pigs, potentially allowing the pigs to be more responsive to pathogenic infections. However, there is limited information on the effect of yeast products on leukocyte populations, particularly in response to pathogenic challenges.

There are several ways in which yeast are believed to improve immunity. Both live yeast and yeast cell wall have been demonstrated to directly bind pathogenic bacteria, thereby preventing the binding of the bacteria to the intestine and

Abbreviations: ADG, Average daily gain; BW, Body weight; IL-1 $\beta$, Interleukin-1 $\beta$; IL-6, Interleukin-6; NEFA, non-esterified fatty acids; RBC, red blood cells; TNF- $\alpha$, Tumor necrosis factor- $\alpha$; TLR5, Toll-like receptor 5; YCW, Yeast cell wall; WBC, White blood cells. preventing pathogenic actions, thus potentially influencing hostmicrobiome interactions (13). Additionally, components of the cell wall, such as mannan oligosaccharides, may bind directly to the intestinal wall, and thus prevent the binding of bacteria to host epithelial cells $(5,14,15)$, and may directly affect the growth of bacteria within the gut, altering the pathogenicity of the microbiome (16). Both of these actions would suggest a reduction in inflammation in the gut which may alter other immune parameters. Further, components of the cell wall of yeast, such as $\beta$-glucans and mannan oligosaccharides, have been demonstrated to alter immune function $(5,17)$, through activation of pattern recognition receptors and other responses, although the immune response elicited may be influenced by the overall health status of the animal (18). Approximately $70 \%$ of immune tissues are associated with the gastrointestinal tract (19). Reduction in inflammation within the gut may result in changes in other immune parameters, allowing for improved immune responses. Further, reduction in gut inflammation may improve gut integrity, reduce pathogen migration from the gastrointestinal tract, thus reducing overall systemic inflammation (20). However, much of this is speculation based on human and rodent models and has not been investigated in livestock species. Based on the potential effects of yeast products on enhancing immunity, it was hypothesized that supplementation with yeast cell wall would improve growth while altering populations of various circulating leukocyte populations and reducing bacteria concentrations within the gastrointestinal tract. Therefore, the objective of this study was to evaluate the performance and changes in leukocyte populations and tissue and digesta Salmonella concentrations of newly-weaned pigs supplemented with yeast cell wall products when orally challenged with Salmonella enterica serotype Typhimurium. Salmonella is one of the major pathogens associated with postweaning diarrhea in pigs, with Typhimurium being the serotype most prevalent in swine (21). The use of a live Salmonella challenge in weaned pigs was used in this study to mimic postweaning Salmonellosis in a controlled manner that produced mild to moderate morbidity in order to determine any potential effects of yeast cell wall supplementation.

\section{MATERIALS AND METHODS}

\section{Experimental Design}

All experimental procedures were in compliance with the Guide for the Care and Use of Agricultural Animals in Research and Teaching and approved by the Institutional Animal Care and Use Committee at the Livestock Issues Research Unit. 


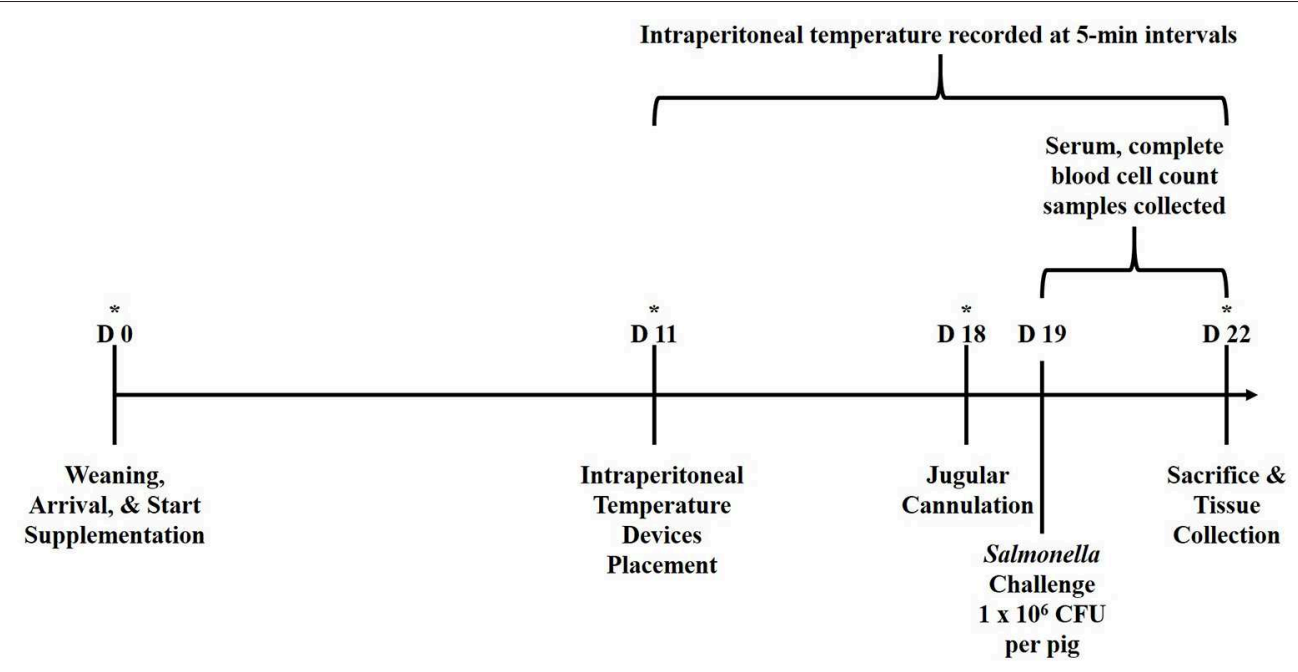

FIGURE 1 | Graphical representation of the study experimental design relative to $d$ of study. Pigs were $\sim 21 \mathrm{~d}$ of age at the time of weaning (d 0$)$. *Represents time points in which performance data (pig and feeder weights) were collected. Serum and CBC samples were collected at 6-h intervals from -6 to $72 \mathrm{~h}$ relative to Salmonella challenge at $\mathrm{O} \mathrm{h}$.

The experimental design is outlined in Figure 1. Newly weaned crossbred pigs $(n=39$; barrows, $\sim 21 \mathrm{~d}$ of age) were acquired from a commercial swine producer in Kansas, USA and transported approximately $480 \mathrm{~km}$ to the Livestock Issues Research Unit's Liberty Farm facility in Lubbock, Texas, USA. Pigs were housed in an enclosed, environmentally-controlled facility in individual stainless-steel pens $(1.2 \times 0.6 \mathrm{~m})$ equipped with stainless steel feeders and nipple waterers. Pigs were weighed upon arrival ( $\mathrm{d}$ 0) and balanced by body weight (BW) to one of three treatment diets $(n=13 /$ treatment): (1) Control, fed a non-medicated starter ration; (2) fed the Control ration supplemented with yeast cell wall at $250 \mathrm{mg} / \mathrm{kg}$ BW (YCW250; Phileo Lesaffre Animal Care, Milwaukee, Wisconsin, USA); or (3) fed the Control ration supplemented with yeast cell wall at $500 \mathrm{mg} / \mathrm{kg} \mathrm{BW}$ (YCW500). The YCW product used in the study was a commercially available product that was a proprietary combination of two cell walls from Saccharomyces cerevisiae (C-Wall, Phileo Lessaffre Animal Care). Pigs were provided corn/soybean meal-based treatment rations that was formulated to meet or exceeded NRC recommendations and water ad libitum for $22 \mathrm{~d}$. Pigs and feeders were weighed weekly, and feed was added to feeders as needed to allow for ad libitum feed intake. On d 11, pigs were anesthetized and a small incision ( 2 to $2.5 \mathrm{~cm}$ ) was made in the lower abdominal region for the placement of an indwelling temperature recording device (Star-Oddi DST micro-T; MeterMall USA, Marysville, Ohio, USA) into the peritoneal cavity which measured intraperitoneal temperature continuously every 5 -min until the completion of the study (7). Specifically, pigs were placed ventral side up on a vtrough and mask-induced with $5 \%$ isoflurane and an oxygen flow rate of $2.0-3.0 \mathrm{~L} / \mathrm{min}$. Once pigs were completely anesthetized, isoflurane was reduced to $2.0-3.0 \%$ to maintain the pigs in an anesthetized state. At this point, $0.5 \mathrm{~mL}$ of lidocaine was applied subcutaneously. Next, the lower $1 / 3$ of the abdomen, posterior to the navel, was surgically prepped with three gross scrubs of a diluted betadine solution, followed by a $70 \%$ ethanol wipe. A 2 to $2.5 \mathrm{~cm}$ incision was then made through the skin and muscle layers using a scalpel, lateral to the midline between the second and third teats relative to the posterior of the pig. The temperature recording device was then aseptically placed into the intraperitoneal cavity, and the muscle was sutured close, followed by the skin layer. The entire procedure was completed in $<10 \mathrm{~min}$. Intraperitoneal temperature was measured from the point the last pig had the temperature device placed until collection of the last sample, which encompassed $176 \mathrm{~h}$ prior to the challenge and $72 \mathrm{~h}$ following the challenge.

On d 18, pigs were anesthetized and fitted with indwelling jugular catheters using a non-surgical method (22). The following day (d 19), pigs were orally inoculated with an overnight Tryptic Soy Broth (TSB)-grown culture that was resuspended in fresh TSB (Difco, Detroit, Michigan, USA) to reach a challenge dose of $1 \times 10^{6} \mathrm{CFU} /$ pig at $0 \mathrm{~h}$. The challenge dose was expected, as observed in previous studies at the Food and Feed Safety Research Unit (FFSRU; unpublished data), to produce a mild salmonellosis that resulted in increased diarrhea, lethargy, and reduced feed intake (moderate morbidity), while not resulting in mortality. Salmonella enterica Typhimurium originally isolated from swine and maintained in the FFSRU culture collection was repeatedly grown by $10 \%(\mathrm{vol} / \mathrm{vol})$ transfer in anoxic $\left(85 \% \mathrm{~N}_{2}\right.$, $10 \% \mathrm{CO}_{2}, 5 \% \mathrm{H}_{2}$ atmosphere) Tryptic soy broth (TSB) medium at $37^{\circ} \mathrm{C}$. This strain was selected for resistance to novobiocin and nalidixic acid ( 20 and $25 \mu \mathrm{g} / \mathrm{mL}$, respectively) by repeated transfer and selection in the presence of sub-lethal concentrations of each antibiotic. This resistant phenotype was stable through multiple unselected transfers in batch culture and through repeated culture vessel turnovers in continuous culture (data not shown). Overnight cultures were harvested by centrifugation $(7,500 \mathrm{x} \mathrm{g}, 10 \mathrm{~min})$ and cell pellets were re-suspended in TSB 
medium. One $4.5 \mathrm{~mL}$ whole blood sample was collected in Starstedt tubes containing no additive (Starstedt Inc., Newton, North Carolina, USA) at 6 -h intervals from -6 to $72 \mathrm{~h}$ relative to the oral Salmonella challenge. Samples were allowed to clot at room temperature for $30 \mathrm{~min}$ prior to centrifugation at $1,500 \mathrm{~g}$ for $20 \mathrm{~min}$ at $4^{\circ} \mathrm{C}$. Isolated serum was stored at $-80^{\circ} \mathrm{C}$ until analyzed for cortisol, glucose and non-esterified fatty acid (NEFA) concentrations. A second 4-mL sample was collected in a vacutainer tube (Fisher Scientific, Pittsburgh, Pennsylvania, USA) containing EDTA for determination of red blood cell, hemoglobin, hematocrit, platelet, total white blood cell (WBC) and differential counts using a Procyte Dx Hematology Analyzer (IDEXX, Westbrook, Maine, USA) using porcine-specific analogs. Fecal samples were collected at 0, 24, and $48 \mathrm{~h}$ following challenge and quantified for Salmonella concentrations (described below). Following collection of the $72 \mathrm{~h}$ blood samples, all pigs were humanely euthanized, and tissue samples from the ileocecal lymph node, and tissue and digesta samples from the cecum, colon, and rectum were collected for quantification of Salmonella concentrations. The rectum sample collected at $72 \mathrm{~h}$ post-challenge was assumed as the $72-\mathrm{h}$ fecal sample.

\section{Serum Analysis}

All serum samples were analyzed in duplicate and serum cortisol concentrations were determined using a commerciallyavailable, porcine-specific enzyme immunoassay kit (Abnova, Taiwan) according to the manufacturers' directions. The intraand inter-assay coefficients of variation were 13.2 and $16.5 \%$, respectively. Serum glucose concentrations were determined by modification of the enzymatic Autokit Glucose (Wako Diagnostics, Richmond, Virginia, USA) to fit a 96-well format as previously described (23). Briefly, $300 \mu \mathrm{L}$ of prepared working solution was added to $2 \mu \mathrm{L}$ of serum or prepared standards in a 96-well plate. Plates were incubated at $37^{\circ} \mathrm{C}$ for $5 \mathrm{~min}$ and absorption was recorded at $505 \mathrm{~nm}$. The plate reader used for this assay has an incubating and timing feature and therefore ensured that the sample absorbances were read immediately following the 5-min incubation. Concentrations of glucose were determined by comparing unknown samples to a standard curve of known glucose concentrations. The intra- and inter-assay coefficients of variation were 8.5 and $9.6 \%$, respectively. Serum NEFA concentrations were determined by modification of the enzymatic HR Series NEFA-HR (2) assay (Wako Diagnostics, Richmond, Virginia, USA) to fit a 96-well format as previously described (23). Briefly, $200 \mu \mathrm{L}$ of the prepared Color Reagent A was added to $5 \mu \mathrm{L}$ of serum or prepared standards in a 96-well plate. Plates were incubated at $37^{\circ} \mathrm{C}$ for $5 \mathrm{~min}$ and then the absorbance was read using a plate reader at $550 \mathrm{~nm}$. Next, $100 \mu \mathrm{L}$ of prepared Color Reagent B was added to all wells on the 96-well plate. Plates were incubated for an additional $5 \mathrm{~min}$ and read for a second time using a plate reader at $550 \mathrm{~nm}$. The plate reader used for this assay has an incubating timing feature which therefore ensured that the sample absorbances were read immediately following the 5-min incubation. A final absorbance was obtained by subtracting the first reading, which was multiplied by a factor of 0.67 to account for volume changes, from the second reading. Final absorbance values were used for all calculations (i.e., standard curve, sample concentrations). Concentrations of NEFAs were determined by comparing unknown samples to a standard curve of known NEFA concentrations. The intra- and inter-assay coefficients of variation were 12.9 and $15.5 \%$, respectively.

\section{Fecal and Tissue Salmonella Analysis}

Prior to experimental infection, fecal samples from all pigs were collected and enriched to confirm the absence of Salmonella and to ensure that no bacteria with similar morphology resistant to nalidixic acid were present. For qualitative enrichment of Salmonella, $3 \mathrm{~g}$ of aseptically collected tissue or digesta were added to tubes containing $27 \mathrm{~mL}$ of Tetrathionate broth (Difco Laboratories, Detroit, Michigan, USA) and incubated at $37^{\circ} \mathrm{C}$ for $24 \mathrm{~h}$. After this incubation, $200 \mu \mathrm{L}$ of the Tetrathionate enrichment were added to $5 \mathrm{~mL}$ Rappaport-Vassiliadis R10 broth (24) and incubated an additional $24 \mathrm{~h}$ at $42^{\circ} \mathrm{C}$ before being streak-plated onto brilliant green agar (BGA) supplemented with novobiocin $(25 \mu \mathrm{g} / \mathrm{mL})$ and nalidixic acid $(20 \mu \mathrm{g} / \mathrm{mL})$. Plates were incubated for $24 \mathrm{~h}$ at $37^{\circ} \mathrm{C}$; colonies that exhibited typical Salmonella morphology (pink/white, opaque, circular, entire, convex colonies of a medium size surrounded by a brilliant red medium [alkaline]) were individually picked for further biochemical characterization. Putative Salmonella colonies were picked and inoculated onto Triple Sugar Iron (TSI) agar slants and Lysine Iron agar (LIA) slants (Difco Laboratories). Each slant was incubated at $37^{\circ} \mathrm{C}$ for $24 \mathrm{~h}$. Salmonella-positive samples were confirmed by slide agglutination using SM-O antiserum poly A-I and V-I, and group C1 factors. Salmonella isolates were stored in glycerol and TSB at $-80^{\circ} \mathrm{C}$ until confirmatory serotyping was performed by the National Veterinary Services Laboratory (NVSL) in Ames, IA.

\section{Statistical Analysis}

Prior to data analysis, intraperitoneal temperature data were averaged into 1 -h intervals. With the exception of performance and Salmonella count data, all data were analyzed separately in two time blocks, Pre-challenge ( -6 and $0 \mathrm{~h})$, and Postchallenge ( 0 to $72 \mathrm{~h}$ ). Performance, serum, and hematology data were analyzed using the MIXED procedure of SAS, specific for repeated measures. Treatment, time, and treatment $\mathrm{x}$ time were included as fixed effects, and pig within treatment was included as the subject. When significant, specific treatment differences were separated using the PDIFF option in SAS. Salmonella tissue and fecal count data were analyzed in SAS using Proc Glimmix of SAS at an $\alpha=0.05$ utilizing the Tukey option for mean separation. $P<0.05$ was considered significant, and $0.05 \leq P \leq 0.10$ was considered a tendency.

\section{RESULTS}

\section{Performance and Intraperitoneal Temperature}

Pig body weight was not different between treatments $(P=0.49)$ but increased over time, as expected $(P<0.001)$. There was a tendency $(P=0.07)$ for ADG to be reduced in YCW500 
TABLE 1 | Performance parameters measured in pigs fed a control (Control) diet or supplemented with a yeast cell wall at $250 \mathrm{mg} / \mathrm{kg}$ (YCW250) or 500 mg/kg (YCW500), with administration of an oral Salmonella Typhimurium challenge on d 19.

\begin{tabular}{|c|c|c|c|c|c|c|c|c|c|}
\hline \multirow[b]{2}{*}{ Variable } & \multirow[b]{2}{*}{ TRT } & \multicolumn{4}{|c|}{ Day of study } & \multirow[b]{2}{*}{ SEM } & \multicolumn{3}{|c|}{$P$-value } \\
\hline & & 0 & 11 & 18 & 22 & & TRT $^{\mathrm{C}}$ & Time & Interaction $^{d}$ \\
\hline \multirow[t]{3}{*}{ Weight (kg) } & Control & 7.13 & 7.70 & 10.75 & 11.96 & 0.30 & 0.49 & $<0.001$ & 0.68 \\
\hline & YCW250 & 7.04 & 7.65 & 10.14 & 11.79 & 0.32 & & & \\
\hline & YCW500 & 7.35 & 7.85 & 10.10 & 11.34 & 0.30 & & & \\
\hline \multirow[t]{3}{*}{$\operatorname{ADG}(\mathrm{kg} / \mathrm{d})^{\mathrm{a}}$} & Control & & 0.05 & 0.43 & 0.30 & 0.03 & 0.07 & $<0.001$ & 0.11 \\
\hline & YCW250 & & 0.06 & 0.36 & 0.40 & 0.03 & & & \\
\hline & YCW500 & & 0.04 & 0.31 & 0.29 & 0.03 & & & \\
\hline \multirow[t]{3}{*}{ Feed Disappearance (kg) } & Control & & 1.69 & 3.70 & 2.48 & 0.19 & 0.08 & $<0.001$ & 0.80 \\
\hline & YCW250 & & 1.57 & 3.10 & 2.13 & 0.21 & & & \\
\hline & YCW500 & & 1.57 & 3.38 & 2.24 & 0.20 & & & \\
\hline \multirow[t]{3}{*}{$\mathrm{G}: \mathrm{F}(\mathrm{kg})^{\mathrm{b}}$} & Control & & 0.28 & 0.83 & 0.49 & 0.07 & 0.01 & $<0.001$ & 0.35 \\
\hline & YCW250 & & 0.40 & 0.79 & 0.76 & 0.08 & & & \\
\hline & YCW500 & & 0.21 & 0.66 & 0.53 & 0.07 & & & \\
\hline
\end{tabular}

${ }^{a} A D G$, average daily gain.

${ }^{b} \mathrm{G}: F$, gain to feed.

${ }^{c}$ TRT, Treatment.

${ }^{d}$ Interaction, Treatment $x$ time.

Bold text represents significant values.

compared to YCW250, while Control ADG was intermediate. Additionally, there was a tendency $(P=0.08)$ for a treatment effect on feed intake, with feed intake reduced in YCW250 pigs compared to Control, and with YCW500 pigs being intermediate. There was a treatment effect $(P=0.01)$ on gain:feed which was greater in YCW250 compared to both Control and YCW500 pigs. Performance data are summarized in Table $\mathbf{1 .}$

Intraperitoneal temperature over the $176 \mathrm{~h}(7.3 \mathrm{~d})$ prior to the Salmonella challenge was greater $(P<0.001)$ in the YCW250 pigs compared to Control and YCW500 pigs (Figure 2A; Table 2). There was a treatment $\mathrm{x}$ time interaction for post-challenge intraperitoneal temperature (Figure 2A; Table 4). Specifically, YCW250 pigs had reduced $(P \leq 0.05)$ intraperitoneal temperature than Control pigs from 3 to $15 \mathrm{~h}$, 55 to $56 \mathrm{~h}, 61$ to $63 \mathrm{~h}$, and 67 to $69 \mathrm{~h}$, yet YCW250 had greater intraperitoneal temperature than Control pigs at $30 \mathrm{~h}$ $(P=0.05)$. Additionally, YCW500 pigs had reduced $(P \leq 0.04)$ intraperitoneal temperature than Control pigs from 3 to $6 \mathrm{~h}, 8$ to $10 \mathrm{~h}$, and at $45 \mathrm{~h}$ post-challenge. Lastly, YCW250 pigs had greater $(P \leq 0.05)$ intraperitoneal temperature than YCW500 pigs from 20 to $22 \mathrm{~h}$. Based on baseline treatment differences in intraperitoneal temperature, the post-challenge temperature data was analyzed as the change in intraperitoneal temperature relative to average baseline values. There was a treatment $\mathrm{x}$ time interaction for the change in intraperitoneal temperature $(P=0.002$; Figure 2B; Table 4). Control pigs had a greater change in intraperitoneal temperature than YCW250 pigs from 3 to $17 \mathrm{~h}$, at $38 \mathrm{~h}$, from 55 to $58 \mathrm{~h}$, from 61 to $64 \mathrm{~h}$, and from 67 to $71 \mathrm{~h}$. Control pigs also had greater change in intraperitoneal temperature than YCW500 pigs from 3 to $10 \mathrm{~h}$, and at $45 \mathrm{~h}$. Finally, the change in intraperitoneal temperature was greater in YCW500 than YCW250 pigs from 4 to $5 \mathrm{~h}$, from 14 to $15 \mathrm{~h}$, at $55 \mathrm{~h}$, and from 61 to $69 \mathrm{~h}$ post-challenge.

\section{Serum Analysis}

No treatment differences were observed between groups for serum cortisol concentrations prior to challenge $(P=0.11$; Table 2; Supplementary Table 1). However, following the Salmonella challenge, there was a treatment $\mathrm{x}$ time interaction $(P=0.03$; Table 4; Supplementary Table 3) such that cortisol concentrations were greater in Control pigs than both YCW supplemented groups at $0 \mathrm{~h}$, but was reduced in Control pigs compared to YCW500 pigs at 24 and $30 \mathrm{~h}$. However, it should be noted that throughout the challenge serum cortisol concentrations remained very low (i.e., below $10 \mathrm{ng} / \mathrm{mL}$ ) suggesting as previously observed that cortisol may not be a good indicator of infection.

Serum glucose concentrations did not differ between treatments prior to the challenge $(P=0.17$; Table 2; Supplementary Table 1). Following Salmonella challenge there was a treatment $\mathrm{x}$ time interaction $(P=0.01)$ for serum glucose concentrations (Table 4; Supplementary Table 3). Specifically, glucose was greater in YCW250 than Control pigs at $6 \mathrm{~h}(P=0.02)$, yet at $60 \mathrm{~h} \mathrm{Control} \mathrm{pig} \mathrm{glucose} \mathrm{concentration}$ was greater than in YCW250 pigs $(P=0.02)$. Additionally, YCW250 pigs had greater glucose concentrations at $18 \mathrm{~h}$ compared to YCW500 pigs, but by $30 \mathrm{~h}$ YCW500 pigs had greater glucose concentrations than did YCW250 pigs. Lastly, glucose concentrations were reduced in YCW500 pigs at $72 \mathrm{~h}(P$ $\leq 0.02$ ) compared to the other treatment groups.

Similar to glucose, there was no treatment effect for serum NEFA concentrations prior to administration of Salmonella $(P=0.30$; Table 2; Supplementary Table 1). After challenge, NEFA concentrations were decreased $(P=0.002)$ in both YCW treatment groups compared to Control pigs (Table 4; Supplementary Table 3). Additionally, there was a tendency $(P=0.07)$ for a treatment $\mathrm{x}$ time interaction such that NEFA 
concentrations were greater in Control compared to both YCW treatment groups at 6, 18, 24 (YCW500 only), and 72 $\mathrm{h}$ post-challenge.

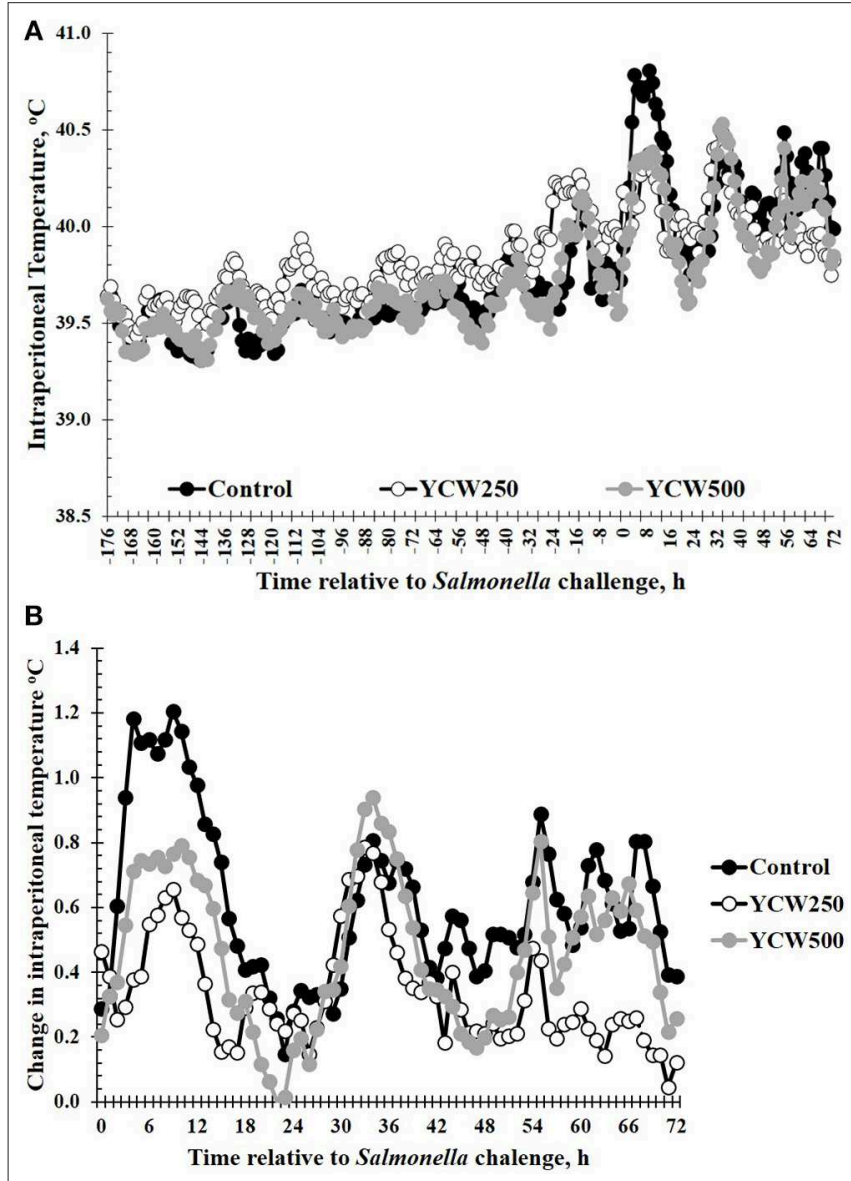

FIGURE 2 | (A) The intraperitoneal temperature response and (B) change in intraperitoneal temperature in pigs fed a control (Control) diet or supplemented with a yeast cell wall at $250 \mathrm{mg} / \mathrm{kg}$ (YCW250) or $500 \mathrm{mg} / \mathrm{kg}$ (YCW500), following administration of an oral Salmonella Typhimurium challenge on d 19. (A) $\mathrm{SEM} \pm 0.12^{\circ} \mathrm{C}$ for all treatment groups; (B) SEM $\pm 0.01^{\circ} \mathrm{C}$ for all treatment groups.

\section{Hematology Analysis}

Prior to administration of the Salmonella challenge, the only hematology variables that were affected by treatment were red blood cell (RBC), platelet, and lymphocyte concentrations (Table 3; $P \leq 0.05$ ). For RBC, the YCW500 pigs had greater pre-challenge concentrations than Control pigs, while both YCW treatment groups had greater platelet concentrations than Control pigs. Lymphocytes were greater in Control and YCW500 treatments compared to YCW250 pigs $(P=0.002$; Table 3). Pre-challenge time effects for hematology variables are summarized in Supplementary Table 2. Following challenge administration, there were treatment effects for RBC, hemoglobin, hematocrit and platelets (Table 5; $P \leq$ $0.002)$, and all four variables, except for platelets, decreased over time $(P<0.001$; Supplementary Table 4$)$. Red blood cell concentrations were greater in YCW250 pigs than Control pigs. Hemoglobin and hematocrit concentrations were greater in Control and YCW250 pigs compared to YCW500 pigs. Platelet concentrations were greater in both YCW treatment groups than Control pigs. There was a treatment $\mathrm{x}$ time interaction for total white blood cell concentrations $(P=0.03$; Figure 3 ). Specifically, Control pigs had greater white blood cell concentrations at $6 \mathrm{~h}$, while all three treatments differed from each other at $12 \mathrm{~h}$, yet YCW250 had reduced white blood cell concentrations at $18 \mathrm{~h}$ compared to Control and YCW500 pigs. Similar to white blood cells, there was a treatment $\mathrm{x}$ time interaction for neutrophil concentrations ( $P=0.02$; Figure 4). Neutrophils were greater in Control than YCW supplemented pigs at 6,12 , and $18 \mathrm{~h}$ (YCW250 only). Lymphocyte concentrations following Salmonella challenge were greater in Control and YCW500 pigs compared to YCW250 pigs (treatment $P<0.001$; Figure 5). There was a treatment $\mathrm{x}$ time interaction $(P=0.03)$ for the neutrophil:lymphocyte ratio such that the ratio was greater in Control pigs than in either YCW treatment group at $6 \mathrm{~h}$ and was elevated in Control compared to YCW250 pigs at $12 \mathrm{~h}$ post challenge (Figure 6). Additionally, the neutrophil:lymphocyte ratio was greater in YCW250 pigs than Control pigs from 30 and $36 \mathrm{~h}$ post-challenge. Post-challenge monocytes were greatest in Control, followed by YCW250 and YCW500 pigs (treatment $P<0.001$; Table 5; Supplementary Table 4). Eosinophils were not affected by treatment $(P=0.55)$, but basophil concentrations

TABLE 2 | Intraperitoneal temperature and serum cortisol, glucose and non-esterified fatty acid (NEFA) concentrations measured in pigs fed a control (Control) diet or supplemented with a yeast cell wall at $250 \mathrm{mg} / \mathrm{kg}$ (YCW250) or $500 \mathrm{mg} / \mathrm{kg}$ (YCW500), prior to administration of an oral Salmonella Typhimurium challenge on d 19.

\begin{tabular}{|c|c|c|c|c|c|c|c|}
\hline \multirow[b]{2}{*}{ Variable } & \multirow[b]{2}{*}{ Control $^{1}$} & \multirow[b]{2}{*}{ YCW250 } & \multirow[b]{2}{*}{ YCW500 } & \multirow[b]{2}{*}{ SEM } & \multicolumn{3}{|c|}{ Pre-challenge $\boldsymbol{P}$-values } \\
\hline & & & & & $\mathrm{TRT}^{2}$ & Time & Interaction $^{3}$ \\
\hline $\mathrm{IP}^{4}$ temperature $\left({ }^{\circ} \mathrm{C}\right)$ & $39.58^{b}$ & $39.75^{\mathrm{a}}$ & $39.58^{b}$ & 0.01 & $<0.001$ & $<0.001$ & 1.00 \\
\hline Cortisol (ng/mL) & 7.29 & 4.73 & 6.51 & 0.92 & 0.11 & 0.004 & 0.34 \\
\hline Glucose (mg/dL) & 90.41 & 94.66 & 88.12 & 2.50 & 0.17 & 0.23 & 0.53 \\
\hline NEFA (mmol/L) & 0.14 & 0.14 & 0.12 & 0.01 & 0.30 & 0.14 & 0.91 \\
\hline
\end{tabular}

${ }^{a b}$ Treatments with different superscripts within rows differ $(P \leq 0.05)$.

${ }^{1}$ Values for Control and YCW treatments represent average values across all time points.

${ }^{2}$ TRT, Treatment

${ }^{3}$ Interaction, Treatment $x$ time.

${ }^{4}$ IP, intraperitoneal.

Bold text represents significant values. 
TABLE 3 | Complete blood cell count parameters measured in pigs fed a control (Control) diet or supplemented with a yeast cell wall at 250 mg/kg (YCW250) or 500 $\mathrm{mg} / \mathrm{kg}$ (YCW500), prior to administration of an oral Salmonella Typhimurium challenge on d 19.

\begin{tabular}{|c|c|c|c|c|c|c|c|}
\hline \multirow[b]{2}{*}{ Variable } & \multirow[b]{2}{*}{ Control $^{1}$} & \multirow[b]{2}{*}{ YCW250 } & \multirow[b]{2}{*}{ YCW500 } & \multirow[b]{2}{*}{ SEM } & \multicolumn{3}{|c|}{ Pre-challenge $\boldsymbol{P}$-values } \\
\hline & & & & & $\mathrm{TRT}^{2}$ & Time & Interaction $^{3}$ \\
\hline Red blood cells $\left(10^{6} / \mu \mathrm{L}\right)$ & $5.28^{b}$ & $5.50^{\mathrm{ab}}$ & $5.59^{a}$ & 0.09 & 0.05 & 0.22 & 0.87 \\
\hline Hemoglobin (g/dL) & 8.69 & 8.84 & 8.83 & 0.13 & 0.64 & 0.26 & 0.84 \\
\hline Hematocrit (\%) & 28.20 & 28.59 & 28.51 & 0.46 & 0.82 & 0.23 & 0.83 \\
\hline Platelets $\left(10^{3} / \mu \mathrm{L}\right)$ & $324.86^{b}$ & $393.21^{\mathrm{a}}$ & $401.17^{\mathrm{a}}$ & 18.90 & 0.01 & 0.56 & 0.83 \\
\hline White blood cells $\left(10^{3} / \mu \mathrm{L}\right)$ & 19.06 & 16.80 & 17.16 & 0.95 & 0.20 & 0.95 & 0.90 \\
\hline Neutrophils $\left(10^{3} / \mu \mathrm{L}\right)$ & 6.82 & 6.68 & 5.64 & 0.85 & 0.55 & 0.83 & 0.94 \\
\hline 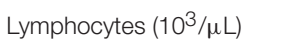 & $10.41^{\mathrm{a}}$ & $8.30^{b}$ & $9.83^{\mathrm{a}}$ & 0.41 & 0.002 & 0.67 & 0.96 \\
\hline$N: L^{4}$ & 0.67 & 0.82 & 0.67 & 0.11 & 0.43 & 0.78 & 0.91 \\
\hline Monocytes $\left(10^{3} / \mu \mathrm{L}\right)$ & 0.05 & 0.17 & 0.12 & 0.11 & 0.31 & 0.76 & 0.97 \\
\hline Eosinophils $\left(10^{3} / \mu \mathrm{L}\right)$ & 0.24 & 0.27 & 0.28 & 0.05 & 0.60 & 0.15 & 0.60 \\
\hline Basophils $\left(10^{3} / \mu \mathrm{L}\right)$ & 0.03 & 0.03 & 0.01 & 0.01 & 0.34 & 0.96 & 0.17 \\
\hline
\end{tabular}

${ }^{a b}$ Treatments with different superscripts within rows differ $(P \leq 0.05)$.

${ }^{1}$ Values for Control and YCW treatments represent average values across all time points.

2 TRT: Treatment.

${ }^{3}$ Interaction: Treatment $x$ time.

${ }^{4} \mathrm{~N}$ :L: Neutrophil:Iymphocyte ratio.

Bold text represents significant values.

TABLE 4 | Intraperitoneal temperature, serum cortisol, glucose, and non-esterified fatty acid (NEFA) concentrations measured in pigs fed a control (Control) diet or supplemented with a yeast cell wall at 250 mg/kg (YCW250) or 500 mg/kg (YCW500), following administration of an oral Salmonella Typhimurium challenge on d 19 .

\begin{tabular}{|c|c|c|c|c|c|c|c|}
\hline \multirow[b]{2}{*}{ Variable } & \multirow[b]{2}{*}{ Control $^{1}$} & \multirow[b]{2}{*}{ YCW250 } & \multirow[b]{2}{*}{ YCW500 } & \multirow[b]{2}{*}{ SEM } & \multicolumn{3}{|c|}{ Post-challenge $P$-values } \\
\hline & & & & & $\mathrm{TRT}^{2}$ & Time & Interaction ${ }^{3}$ \\
\hline $\mathrm{IP}^{4}$ temperature $\left({ }^{\circ} \mathrm{C}\right)$ & $40.21^{a}$ & $40.05^{b}$ & $40.06^{b}$ & 0.01 & $<0.001$ & $<0.001$ & 0.03 \\
\hline IP temperature Change $\left({ }^{\circ} \mathrm{C}\right)$ & $0.61^{a}$ & $0.34^{\mathrm{C}}$ & $0.46^{b}$ & 0.01 & $<0.001$ & $<0.001$ & 0.002 \\
\hline Cortisol (ng/mL) & 3.96 & 4.11 & 4.68 & 0.26 & 0.09 & $<0.001$ & 0.03 \\
\hline Glucose (mg/dL) & 93.78 & 93.20 & 93.32 & 1.22 & 0.93 & $<0.001$ & 0.01 \\
\hline NEFA (mmol/L) & $0.17^{a}$ & $0.14^{b}$ & $0.14^{b}$ & 0.01 & 0.002 & 0.06 & 0.07 \\
\hline
\end{tabular}

${ }^{a b}$ Treatments with different superscripts within rows differ $(P \leq 0.05)$.

${ }^{1}$ Values for Control and YCW treatments represent average values across all time points.

${ }^{2}$ TRT: Treatment.

${ }^{3}$ Interaction: Treatment $x$ time.

${ }^{4} I P$ : intraperitoneal.

Bold text represents significant values.

were greater in YCW250 compared to Control and YCW500 pigs $(P<0.001)$.

\section{Fecal and Tissue Salmonella Analysis}

Salmonella was only detected in the ileocecal lymph nodes in 14 of the 39 pigs (4 Control, 5 YCW250, and 5 YCW500). There was no effect of treatment $(P=0.17)$ on fecal Salmonella counts collected daily through $72 \mathrm{~h}$ post-challenge (Table 6). However, there was an effect of time $(P=0.02)$, such that Salmonella counts decreased from $24 \mathrm{~h}$ to $48 \mathrm{~h}$ post-challenge. Additionally, there was a tendency $(P=0.09)$ for a treatment $\mathrm{x}$ time interaction, where YCW250 pigs had greater fecal Salmonella counts than YCW500 pigs at $24 \mathrm{~h}$, and YCW500 pigs had greater fecal Salmonella counts than Control pigs at $48 \mathrm{~h}$. There was no effect of treatment on Salmonella counts in the rectum, colon, or cecum $(P \geq 0.14$; Table 6).

\section{DISCUSSION}

There were no treatment differences for fecal Salmonella shedding, nor in the Salmonella content of the cecum, colon or rectum. A study using a different challenge strain of Salmonella Typhimurium in pigs observed increased fecal shedding of Salmonella when fed a yeast fermentation product (25). Similar to the current study, another group of investigators found pigs supplemented with yeast as a source of mannan oligosaccharides had no effect on fecal bacterial counts, including Salmonella and E. coli (26). Therefore, it is possible that yeast products have minimal effects on the fecal shedding of Salmonella in pigs. Additionally, less than half of the ileocecal lymph nodes were positive for Salmonella in the current study. This suggests that either the inoculating concentration or strain pathogenicity was insufficient to overwhelm intestinal immunity and mesenteric lymph nodes allowing system migration. This would explain 
TABLE 5 | Complete blood cell count parameters measured in pigs fed a control (Control) diet or supplemented with a yeast cell wall at 250 mg/kg (YCW250) or 500 $\mathrm{mg} / \mathrm{kg}$ (YCW500), following administration of an oral Salmonella Typhimurium challenge on d 19.

\begin{tabular}{|c|c|c|c|c|c|c|c|}
\hline \multirow[b]{2}{*}{ Variable } & \multirow[b]{2}{*}{ Control $^{1}$} & \multirow[b]{2}{*}{ YCW250 } & \multirow[b]{2}{*}{ YCW500 } & \multirow[b]{2}{*}{ SEM } & \multicolumn{3}{|c|}{ Post-challenge $\boldsymbol{P}$-values } \\
\hline & & & & & $\mathrm{TRT}^{2}$ & Time & Interaction $^{3}$ \\
\hline Red blood cells $\left(10^{6} / \mu \mathrm{L}\right)$ & $5.13^{b}$ & $5.30^{\mathrm{a}}$ & $5.21^{\mathrm{ab}}$ & 0.03 & 0.002 & $<0.001$ & 0.81 \\
\hline Hemoglobin (g/dL) & $8.37^{\mathrm{a}}$ & $8.41^{\mathrm{a}}$ & $8.16^{\mathrm{b}}$ & 0.05 & 0.001 & $<0.001$ & 0.93 \\
\hline Hematocrit (\%) & $27.60^{\mathrm{a}}$ & $27.26^{\mathrm{a}}$ & $26.54^{b}$ & 0.20 & $<0.001$ & $<0.001$ & 0.87 \\
\hline Platelets $\left(10^{3} / \mu \mathrm{L}\right)$ & $359.51^{b}$ & $392.86^{a}$ & $395.11^{a}$ & 6.70 & $<0.001$ & 0.09 & 0.99 \\
\hline White blood cells $\left(10^{3} / \mu \mathrm{L}\right)$ & $21.01^{a}$ & $17.75^{b}$ & $18.44^{b}$ & 0.47 & $<0.001$ & $<0.001$ & 0.03 \\
\hline Neutrophils $\left(10^{3} / \mu \mathrm{L}\right)$ & $9.11^{a}$ & $7.96^{\mathrm{ab}}$ & $7.80^{\mathrm{b}}$ & 0.42 & 0.05 & $<0.001$ & 0.02 \\
\hline 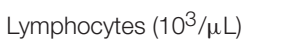 & $9.75^{\mathrm{a}}$ & $7.88^{\mathrm{C}}$ & $8.88^{b}$ & 0.17 & $<0.001$ & 0.25 & 0.52 \\
\hline$N: L^{4}$ & 1.10 & 1.07 & 0.98 & 0.07 & 0.61 & $<0.001$ & 0.03 \\
\hline Monocytes $\left(10^{3} / \mu \mathrm{L}\right)$ & $1.79^{a}$ & $1.58^{\mathrm{b}}$ & $1.44^{\mathrm{C}}$ & 0.04 & $<0.001$ & $<0.001$ & 0.16 \\
\hline Eosinophils $\left(10^{3} / \mu \mathrm{L}\right)$ & 0.34 & 0.26 & 0.29 & 0.05 & 0.55 & 0.08 & 0.87 \\
\hline Basophils $\left(10^{3} / \mu \mathrm{L}\right)$ & $0.02^{b}$ & $0.07^{\mathrm{a}}$ & $0.03^{b}$ & 0.01 & $<0.001$ & 0.33 & 0.31 \\
\hline
\end{tabular}

${ }^{a b c}$ Treatments with different superscripts within rows differ $(P \leq 0.05)$.

${ }^{1}$ Values for Control and YCW treatments represent average values across all time points.

${ }^{2}$ TRT, Treatment.

${ }^{3}$ Interaction, Treatment $x$ time.

${ }^{4} \mathrm{~N}: L$, Neutrophil:Iymphocyte ratio.

Bold text represents significant values.

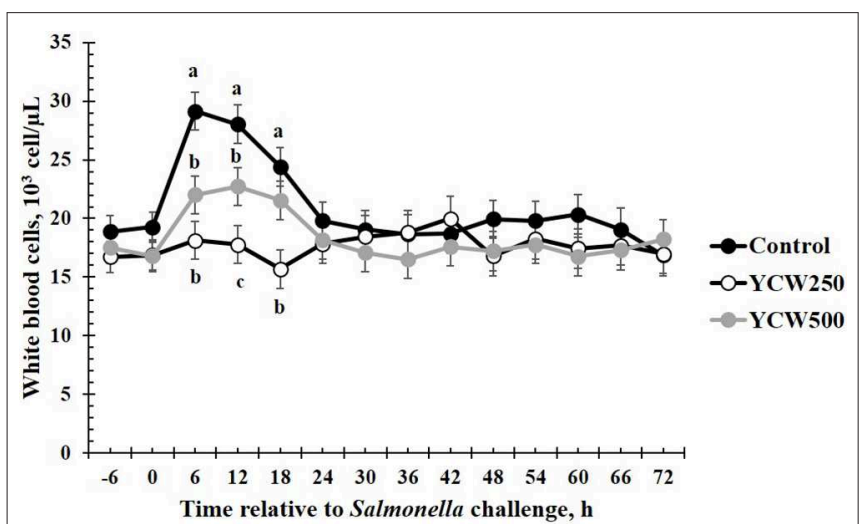

FIGURE 3 | White blood cell concentrations measured in pigs fed a control (Control) diet or supplemented with a yeast cell wall at $250 \mathrm{mg} / \mathrm{kg}$ (YCW250) or $500 \mathrm{mg} / \mathrm{kg}$ (YCW500), following administration of an oral Salmonella Typhimurium challenge on d 19. abc Treatments differ $P<0.02$. the limited intraperitoneal temperature response, as well as the limited effects on the hematological parameters measured in this study. While no differences in Salmonella shedding or tissue content were observed, it is possible that there were effects of the YCW supplement on other aspects of gut microbial populations, as has been observed in other species (18). Future studies may benefit from analyzing effects of YCW supplements on the entire gut microbiome, and the influence of any microbiome population changes on the overall health of the animal.

One of the earliest indicators of illness is reduced growth performance because animals that are sick typically reduce or eliminate feed intake. This was evident in the current study in which feed intake was reduced in all treatments following Salmonella challenge. Interestingly, the YCW500 treatment had

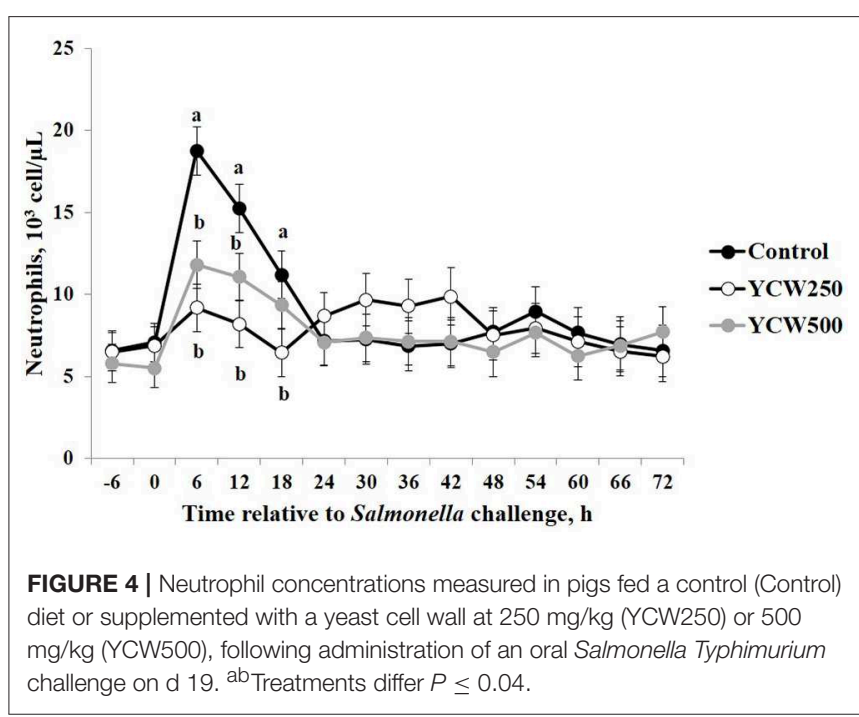

reduced ADG, suggesting that the level of YCW supplementation may have been too high and may consequently have impaired performance. Previous studies utilizing pigs supplemented with a yeast fermentation product also found limited differences in performance (7). Studies using yeast cell wall extract from Saccharomyces cerevisiae found improved ADG in weaned pigs when fed at 0.05 to $0.15 \%$ of the diet (27). However, another study found no effects on performance when a yeast cell wall extract was fed to young pigs (28).

Beta-glucans, a component of the cell wall of yeast, have been demonstrated to have a role in pig growth. Specifically, $\beta$-glucans promote a healthy gut by increasing mucosal barrier functions through modulating the intestinal microbiota and supporting the immune system in the gut (29). Additionally, supplementation 
of pigs with Saccharomyces cerevisiae boulardii has increased villus height and crypt depth within the small intestine, while decreasing goblet cells $(30,31)$. Bontempo, Di Giancamillo (31)
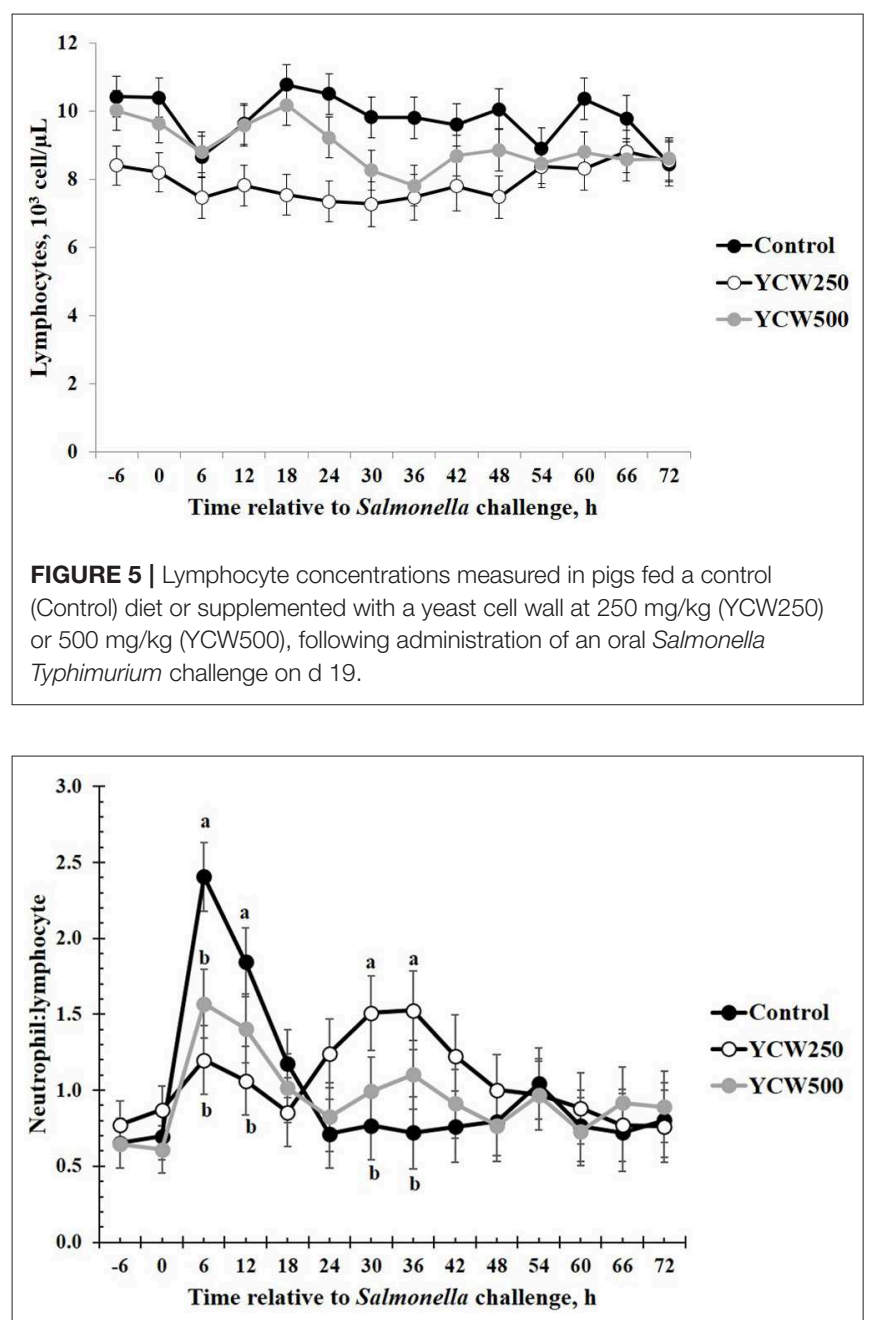

FIGURE 6 | The neutrophil:lymphocyte ratio measured in pigs fed a control (Control) diet or supplemented with a yeast cell wall at $250 \mathrm{mg} / \mathrm{kg}$ (YCW250) or $500 \mathrm{mg} / \mathrm{kg}$ (YCW500), following administration of an oral Salmonella Typhimurium challenge on d 19. ${ }^{\text {ab }}$ Treatments differ $P<0.03$. found an increase in the mucin content of goblet cells within the ileum, while observing a decrease in mucous layer thickness in yeast supplemented pigs compared to control pigs. The authors suggested that the greater mucous thickness may be a result of greater pathogenic bacteria in the gut of control pigs compared to those pigs supplemented with live yeast, and may also reduce nutrient absorption, and thus reduce growth in control pigs.

An increase in body temperature in response to a bacterial challenge is common, as fever enhances bacterial killing efficacy of the immune system (32). The intraperitoneal temperature response in the current study is similar in temporal pattern and magnitude to that of previous Salmonella challenge studies $(33,34)$. However, a study by Balaji et al. (35) demonstrated an increase in body temperature sooner, within $12 \mathrm{~h}$ of challenge, with a greater dose of Salmonella Typhimurium, whereas a Salmonella-induced increase was not observed until approximately $42 \mathrm{~h}$ post-challenge in the current study, as discussed further below. It is possible that the greater challenge dose resulted in increases in rectal temperature more quickly in the aforementioned study than in the current study. Additionally, there could be differences in the manner in which body temperature was measured, as the previous study utilized measuring rectal temperature every $6 \mathrm{~h}$, which the current study utilized an indwelling temperature probe in the intraperitoneal cavity that measured temperature continuously every $5 \mathrm{~min}$. The difference in intraperitoneal temperature prior to the challenge is of interest as it occurred in only one treatment group, the YCW250 treatment. Similar to the differences observed in performance, it suggests a potential benefit from the $250 \mathrm{mg} / \mathrm{kg}$ dose but not the $500 \mathrm{mg} / \mathrm{kg}$ dose, as Control and YCW500 had similar body temperatures prior to the challenge.

The post-challenge temperature response was very interesting. First, there was a rapid increase in intraperitoneal temperature immediately following administration of the Salmonella challenge ( 6 to $18 \mathrm{~h}$ ). This response is likely a response to the stress associated with the dosing, as the pigs had to be picked up for the oral Salmonella administration. Data in pigs has demonstrated that restraint stress can result in an increase in body temperature (36). While one could question whether a stress response occurred, due to the lack of a cortisol response, it is important to note that serum samples were only collected every $6 \mathrm{~h}$, which is sufficient time for any acute increase in

TABLE 6 | Fecal and tissue Salmonella counts (log CFU/g) measured in pigs fed a control (Control) diet or supplemented with a yeast cell wall at $250 \mathrm{mg} / \mathrm{kg}$ (YCW250) or $500 \mathrm{mg} / \mathrm{kg}$ (YCW500), following administration of an oral Salmonella Typhimurium challenge on d 19.

\begin{tabular}{|c|c|c|c|c|c|c|c|}
\hline Variable & Control & YCW250 & YCW500 & SEM & TRT $^{\mathrm{a}}$ & Time & Interaction ${ }^{b}$ \\
\hline Fecal $24 \mathrm{~h}$ & 1.15 & 1.98 & 0.95 & 0.37 & 0.17 & 0.02 & 0.09 \\
\hline Fecal $48 \mathrm{~h}$ & 0.00 & 0.33 & 1.29 & 0.37 & & & \\
\hline Fecal $72 \mathrm{~h}^{\mathrm{c}}$ & 0.78 & 1.11 & 1.12 & 0.37 & & & \\
\hline Colon & 0.00 & 0.73 & 0.76 & 0.31 & 0.14 & & \\
\hline Cecum & 0.40 & 1.13 & 0.56 & 0.32 & 0.25 & & \\
\hline
\end{tabular}

a TRT: Treatment.

${ }^{b}$ Interaction: Treatment $x$ time.

${ }^{c}$ Rectum sample means are presented by the Fecal $72 h$ sample; Rectal TRT $P=0.84$. 
cortisol resulting from handling to subside (37). If indeed there was an acute temperature response to the Salmonella challenge, it would be difficult to separate these effects from the effects of the dosing procedure in the current study. Acute effects of Salmonella have not been well-documented in the literature, as most affects appear to be observed at least $12 \mathrm{~h}$ post-challenge in swine. In support of this, a study conducted by Bellido-Carreras, Arguello (38) observed fecal shedding of Salmonella within 1-day post infection which subsequently decreased, while tissue Salmonella content increased from day 1 to day 2 post infection. Further, differences were observed in the timing of leukocyte subset infiltration into tissues. This suggests a distinction between fecal shedding of Salmonella and the tissue Salmonella colonization within the gastrointestinal tract during early infection. Samples for Salmonella enumeration in the current study were not collected until 3 days post infection, and thus the acute period following Salmonella infection is an area that requires further study.

The second interesting portion of the post-challenge temperature response was the increase in intraperitoneal temperature that occurred later in the challenge, beginning approximately $42 \mathrm{~h}$ post challenge until $71 \mathrm{~h}$, particularly in the Control and YCW500 treatment groups. This response, as reported by other studies $(33,34)$, is likely a response to the Salmonella infection. While increases in body temperature are observed in Control and YCW500 groups, there was minimal change in intraperitoneal temperature in the YCW250 group. Salmonella is an intracellular pathogen, eliciting its effects once taken up by intestinal epithelial cells. This action activates the innate immune system, one pathway being through the action of flagellin recognition by toll-like receptor 5 (TLR5), and results in secretion of cytokines such as interleukin-8 (IL-8) into circulation (39). The secretion of IL-8 then stimulates an influx of neutrophils into the intestine in order to kill the Salmonella. Other cytokines that are produced, such as tumor necrosis factor$\alpha$ (TNF- $\alpha)$, also are involved in the initiation of fever in response to pathogenic organisms. A study utilizing an in vitro culture of porcine intestinal cells found a reduction in the adherence of Salmonella in the presence of live yeast, and expression of pro-inflammatory genes in intestinal cell cultures in the presence of Salmonella was reduced, as well as secretion of interleukin-6 (IL-6), another cytokine involved in the development of fever (40). This suggests a reduction in binding of Salmonella to intestinal cells and reduced inflammation in the intestine in the presence of yeast. A reduction in inflammation in the gut may result in reduced systemic inflammation, thus the reduced body temperature observed in the YCW250 pigs. Sweeney, Collins (41) demonstrated that supplementing weaned pigs with $\beta$-glucans isolated from Saccharomyces cerevisiae reduced the population of Enterobacteriaceae within the intestine, specifically the ileum and the colon. Additionally, the authors found proinflammatory gene expression was reduced in the colon. Thus, changes in the microbial populations in the gut in response to the YCW supplement may have altered or reduced inflammatory responses. However, no differences in the Salmonella content within the specific gut tissues and digesta were found in the current study.
There are very few studies that have measured body temperature in yeast-supplemented pigs. A study utilizing an $E$. coli challenge in pigs supplemented with an autolyzed yeast found no differences in body temperature between the supplemented and control pigs (42). Additionally, pigs fed a yeast fermentation product and challenged with Salmonella Typhimurium found no differences in rectal temperature measured in supplemented vs. control pigs (25). Interesting, both the aforementioned challenges utilized greater bacterial challenge doses than the current study.

Cortisol is often activated concurrently with the immune system where it helps regulate and coordinate the inflammatory and anti-inflammatory responses of the immune system. Changes in cortisol have been previously observed in cattle supplemented with yeast products and exposed to an endotoxin challenge $(8,10)$, and changes in cortisol may provide insight into any changes observed in immune parameters. Limited differences in cortisol were observed during the study and cortisol concentrations remained very low throughout the study. In support of the current study, no difference was found in cortisol concentrations measured at various timepoints within the first $48 \mathrm{~h}$ post-Salmonella infection in finishing barrows (43). Thus, cortisol may not be an important variable to study in response to a live pathogen challenge.

Energy storage and utilization are very important factors associated with the proper functioning of the immune system, as the activated immune system requires a substantial amount of energy $(44,45)$. Additionally, changes in nutrient availability can also directly influence immune cell activation, thus affecting their fate and how the immune cells respond to pathogens (46). Thus, changes in glucose and NEFA concentrations may provide information on changes in energy utilization not only in response to YCW supplementation, but also in response to the Salmonella challenge itself. While glucose and NEFA concentrations differed between YCW treatments at a few time points post-challenge in the current study, there was no consistent effects of treatment on glucose or NEFA concentrations.

The biggest differences observed in the current study were related to hematology parameters. However, when analyzed closely, similar to the temperature response, the differences observed appear to be more related to the stress associated with the challenge administration rather than directly from the Salmonella infection. Specifically, an increase in total white blood cells, neutrophils, and the neutrophil:lymphocyte ratio occur between 6 and $18 \mathrm{~h}$ following the challenge. This is in the same time frame as the increase observed in intraperitoneal temperature. As discussed earlier, handling stress can increase intraperitoneal temperature, but can also increase concentrations of immune cells (47). Thus, it is likely that the increases observed in these particular immune cell parameters are not a result of a Salmonella infection, but rather due to the administration of the challenge. A study by Dubreuil, Farmer (47) reported similar changes in leukocyte profiles, including total leukocytes, neutrophils, lymphocytes and the N:L in pigs exposed to restraint stress for $5 \mathrm{~min}$, in support of the data observed during the current study. Later during the challenge ( 30 to $36 \mathrm{~h}$ postchallenge), an increase in the neutrophil:lymphocyte ratio is 
observed in the YCW250 treatment group compared to Control. As reported earlier, an increase in neutrophil influx to the intestine is one of the first innate immune actions observed in response to Salmonella infection (39). Further, components of the yeast cell wall, such as $\beta$-glucans and mannan oligosaccharides, have been demonstrated to increase production of immune cell populations, including neutrophils and monocytes (5). While there is no statistical increase in neutrophil concentrations in the YCW250 group, lymphocyte concentrations were on average reduced in this treatment group compared to Control pigs. This may account for the treatment differences observed in the neutrophil:lymphocyte ratio during this time period. There were also small differences in monocyte and basophil concentrations between treatments; however, they are not likely of biological significance. Overall, it appears that hematological parameters were influenced more by the stress associated with administration of the challenge, and less influenced by the challenge itself. This is supported by the lack of treatment differences in fecal and tissue Salmonella counts observed in the current study.

\section{CONCLUSIONS}

Weaned pigs supplemented with yeast cell wall had a reduction in the change in intraperitoneal temperature and decreased concentrations of various leukocyte populations in the postchallenge period following an oral Salmonella Typhimurium challenge. However, these responses appear to be more associated with a stress response from administration of the challenge, and less from the actual Salmonella infection. Additionally, there were limited effects on other parameters, including cortisol, glucose, NEFA, and Salmonella counts in feces and lower gastrointestinal tissues. Some of the observed changes in immune cell populations were similar to what has been observed previously in pigs supplemented with yeast products. However, overall there appear to be minimal effects of supplementation with the yeast cell wall product on the acute immune cell response to Salmonella challenge in weaned pigs. Additionally, the data suggest that different dosing rates of yeast cell wall may influence various immune cell populations.

\section{ETHICS STATEMENT}

This study was carried out in accordance with the recommendations of the Guide for the Care and Use of Agricultural Animals in Research and Teaching and approved by the Institutional Animal Care and Use Committee at the Livestock Issues Research Unit.

\section{REFERENCES}

1. Lalles JP, Boudry G, Favier C, Le Floc'h N, Lurona I, Montagne L, et al. Gut function and dysfunction in young pigs: physiology. Anim Res. (2004) 53:301-16. doi: 10.1051/animres:2004018

2. Rauw WM, Kanis E, Noordhuizen-Stassen EN, Grommers FJ. Undesirable side effects of selection for high production efficiency in farm animals: a review. Livest Prod Sci. (1998) 56:15-33. doi: 10.1016/S0301-6226(98)00147-X

\section{AUTHOR CONTRIBUTIONS}

$\mathrm{NB}, \mathrm{JAC}$, and JRC initiated the initial study design. NB, PB, JAC, and TC performed the study and collected data. Data was analyzed and the manuscript was written by NB. All authors reviewed drafts of the manuscript and provided approval prior to submission.

\section{FUNDING}

This work was partially supported by Phileo Lesaffre Animal Care, Milwaukee, WI, USA.

\section{ACKNOWLEDGMENTS}

Mention of trade names or commercial products in this article is solely for the purpose of providing specific information and does not imply recommendation or endorsement by the U.S. Department of Agriculture. The U.S. Department of Agriculture (USDA) prohibits discrimination in all its programs and activities on the basis of race, color, national origin, age, disability, and where applicable, sex, marital status, familial status, parental status, religion, sexual orientation, genetic information, political beliefs, reprisal, or because all or part of an individual's income is derived from any public assistance program. Not all prohibited bases apply to all programs. Persons with disabilities who require alternative means for communication of program information (Braille, large print, audiotape, etc.) should contact USDA's TARGET Center at (202) 720-2600 (voice and TDD). To file a complaint of discrimination, write to USDA, Director, Office of Civil Rights, 1400 Independence Avenue, S.W., Washington, D.C. 20250-9410, or call (800) 795-3272 (voice) or (202) 7206382 (TDD). USDA is an equal opportunity provider and employer. This work was partially supported by Phileo Lesaffre Animal Care. The data presented is an expansion of data previously presented in abstract form (NB, JAC, JRC, PB, Butyn JO, Schmidt TB, TC). Yeast cell wall supplementation alters immune parameters in response to a Salmonella challenge in weaned pigs. J Anim Sci. (2014) 92(E-Suppl. 1):26. The authors would like to thank J. W. Dailey and J. R. Carroll (USDA-ARS) for their excellent technical support.

\section{SUPPLEMENTARY MATERIAL}

The Supplementary Material for this article can be found online at: https://www.frontiersin.org/articles/10.3389/fvets. 2019.00246/full\#supplementary-material

3. Guy SZ, Thomson PC, Hermesch S. Selection of pigs for improved coping with health and environmental challenges: breeding for resistance or tolerance? Front Genet. (2012) 3:281. doi: 10.3389/fgene. 2012.00281

4. Cabrera RA, Boyd RD, Jungst SB, Wilson ER, Johnston ME, Vignes JL, et al. Impact of lactation length and piglet weaning weight on long-term growth and viability of progeny. J Anim Sci. (2010) 88:2265-76. doi: 10.2527/jas. 2009-2121 
5. Kogan G, Kocher A. Role of yeast cell wall polysaccharides in pig nutrition and health protection. Livest Sci. (2007) 109:161-5. doi: 10.1016/j.livsci.2007.01.134

6. Shen Y, Piao X, Kim S, Wang L, Liu P, Yoon I, et al. Effects of yeast culture supplementation on growth performance, intestinal health, and immune response of nursery pigs. J Anim Sci. (2009) 87:2614-24. doi: $10.2527 /$ jas.2008-1512

7. Burdick Sanchez NC, Carroll JA, Broadway PR, Bass BE, Frank JW. Modulation of the acute phase response following a lipopolysaccharide challenge in pigs supplemented with an all-natural Saccharomyces cerevisiae fermentation product. Livest Sci. (2018) 208:1-4. doi: 10.1016/j.livsci.2017.11.022

8. Burdick Sanchez NC, Young TR, Carroll JA, Corley JR, Rathmann RJ, Johnson BJ. Yeast cell wall supplementation alters aspects of the physiological and acute phase responses of crossbred heifers to an endotoxin challenge. Innate Immun. (2013) 19:411-9. doi: 10.1177/1753425912469673

9. Burdick Sanchez NC, Young TR, Carroll JA, Corley JR, Rathmann RJ, Johnson BJ. Yeast cell wall supplementation alters the metabolic responses of crossbred heifers to an endotoxin challenge. Innate Immun. (2014) 20:104-12. doi: 10.1177/1753425913482152

10. Finck D, Ribeiro F, Burdick N, Parr S, Carroll J, Young T, et al. Yeast supplementation alters the performance and health status of receiving cattle. Prof Anim Sci. (2014) 30:333-41. doi: 10.15232/S1080-7446(15)30125-X

11. Hughes HD, Carroll JA, Burdick Sanchez NC, Richeson JT. Natural variations in the stress and acute phase responses of cattle. Innate Immun. (2014) 20:888-96. doi: 10.1177/1753425913508993

12. Collier CT, Carroll JA, Ballou MA, Starkey JD, Sparks JC. Oral administration of Saccharomyces cerevisiae boulardii reduces mortality associated with immune and cortisol responses to Escherichia coli endotoxin in pigs. J Anim Sci. (2011) 89:52-8. doi: 10.2527/jas.2010-2944

13. Perez-Sotelo LS, Talavera-Rojas M, Monroy-Salazar HG, Lagunas-Bernabe $\mathrm{S}$, Cuaron-Ibarguengoytia JA, Jimenez RM, et al. In vitro evaluation of the binding capacity of Saccharomyces cerevisiae Sc47 to adhere to the wall of Salmonella spp. Rev Latinoam Microbiol. (2005) 47:70-5.

14. Spring P, Wenk C, Dawson KA, Newman KE. The effects of dietary mannaoligosaccharides on cecal parameters and the concentrations of enteric bacteria in the ceca of salmonella-challenged broiler chicks. Poult Sci. (2000) 79:205-11. doi: 10.1093/ps/79.2.205

15. Ganner A, Schatzmayr G. Capability of yeast derivatives to adhere enteropathogenic bacteria and to modulate cells of the innate immune system. Appl Microbiol Biotechnol. (2012) 95:289-97. doi: 10.1007/s00253012-4140-y

16. Czarnecki-Maulden G. Effect of dietary modulation of intestinal microbiota on reproduction and early growth. Theriogenology. (2008) 70:286-90. doi: 10.1016/j.theriogenology.2008.05.041

17. Nochta I, Tuboly T, Halas V, Babinszky L. Effect of different levels of mannan-oligosaccharide supplementation on some immunological variables in weaned piglets. J Anim Physiol Anim Nutr. (2009) 93:496-504. doi: 10.1111/j.1439-0396.2008.00835.x

18. Teng PY, Kim WK. Review: roles of prebiotics in intestinal ecosystem of broilers. Front Vet Sci. (2018) 5:245. doi: 10.3389/fvets.2018.00245

19. Jha R, Fouhse JM, Tiwari UP, Li L, Willing BP. Dietary fiber and intestinal health of monogastric animals. Front Vet Sci. (2019) 6:48. doi: 10.3389/fvets.2019.00048.

20. Berg RD. Bacterial translocation from the gastrointestinal tract. Adv Exp Med Biol. (1999) 473:11-30.

21. Kim HB, Isaacson RE. Salmonella in swine: microbiota interactions. Annu Rev Anim Biosci. (2017) 5:43-63. doi: 10.1146/annurev-animal-022516-022834

22. Carroll JA, Daniel JA, Keisler DH, Matteri RL. Non-surgical catheterization of the jugular vein in young pigs. Lab Anim. (1999) 33:129-34. doi: $10.1258 / 002367799780578345$

23. Burdick Sanchez N, Carroll J, Randel R, Vann R, Welsh T. Associations between endotoxin-induced metabolic changes and temperament in Brahman bulls. J Anim Physiol Anim Nutr. (2014) 98:178-90. doi: 10.1111/jpn.12071

24. Difco. Bacto Rappaport-Vassiliadis R10 Broth. The Difco Manual, 11th ed. Sparks, MD: Difco Laboratories (1998).

25. Price KL, Totty HR, Lee HB, Utt MD, Fitzner GE, Yoon I, et al. Use of Saccharomyces cerevisiae fermentation product on growth performance and microbiota of weaned pigs during Salmonella infection. J Anim Sci. (2010) 88:3896-908. doi: 10.2527/jas.2009-2728

26. White L, Newman M, Cromwell G, Lindemann M. Brewers dried yeast as a source of mannan oligosaccharides for weanling pigs. J Anim Sci. (2002) 80:2619-28. doi: 10.1093/ansci/80.10.2619

27. Liu G, Yu L, Martinez Y, Ren WK, Ni HJ, Al-Dhabi NA, et al. Dietary Saccharomyces cerevisiae cell wall extract supplementation alleviates oxidative stress and modulates serum amino acids profiles in weaned piglets. Oxid Med Cell Longev. (2017) 2017:3967439. doi: 10.1155/2017/ 3967439

28. Sauerwein H, Schmitz S, Hiss S. Effects of a dietary application of a yeast cell wall extract on innate and acquired immunity, on oxidative status and growth performance in weanling piglets and on the ileal epithelium in fattened pigs. J Anim Physiol Anim Nutr. (2007) 91:369-80. doi: 10.1111/j.1439-0396.2006.00663.x

29. Vetvicka V, Vannucci L, Sima P. The effects of beta-glucan on pig growth and immunity. Open Biochem J. (2014) 8:89-93. doi: 10.2174/1874091X01408010089

30. Baum B, Liebler-Tenorio E, Enss M, Pohlenz J, Breves G. Saccharomyces boulardii and bacillus cereus var. Toyoi influence the morphology and the mucins of the intestine of pigs. Zeitschrift fur Gastroenterologie. (2002) 40:277-84. doi: 10.1055/s-2002-30116

31. Bontempo V, Di Giancamillo A, Savoini G, Dell'Orto V, Domeneghini C. Live yeast dietary supplementation acts upon intestinal morpho-functional aspects and growth in weanling piglets. Anim Feed Sci Tech. (2006) 129:224-36. doi: 10.1016/j.anifeedsci.2005.12.015

32. Hasday JD, Fairchild KD, Shanholtz C. The role of fever in the infected host. Microbes Infect. (2000) 2:1891-904. doi: 10.1016/S1286-4579(00) 01337-X

33. Burdick Sanchez NC, Broadway PR, Carroll JA, Gart EV, Bryan LK, Lawhon SD. Weaned pigs experimentally infected with Salmonella display sexually dimorphic innate immune rsponses without affecting pathogen colonization patterns. Transl Anim Sci. (2017) 1:69-76. doi: 10.2527/tas 2016.0008

34. Tanaka T, Imai Y, Kumagae N, Sato S. The effect of feeding lactic acid to Salmonella typhimurium experimentally infected swine. J Vet Med Sci. (2010) 72:827-31. doi: 10.1292/jvms.09-0490

35. Balaji R, Wright KJ, Hill CM, Dritz SS, Knoppel EL, Minton JE. Acute phase responses of pigs challenged orally with Salmonella typhimurium. J Anim Sci. (2000) 78:1885-91. doi: 10.2527/2000.7871885x

36. Parrott RF, DM LL. Restraint, but not frustration, induces prostaglandinmediated hyperthermia in pigs. Physiol Behav. (1995) 57:1051-5. doi: 10.1016/0031-9384(94)00343-4

37. Prunier A, Mounier AM, Hay M. Effects of castration, tooth resection, or tail docking on plasma metabolites and stress hormones in young pigs. J Anim Sci. (2005) 83:216-22. doi: 10.2527/2005.831216x

38. Bellido-Carreras N, Arguello H, Zaldivar-Lopez S, Jimenez-Marin A, Martins $\mathrm{RP}$, Arce C, et al. Salmonella Typhimurium infection along the porcine gastrointestinal tract and associated lymphoid tissues. Vet Pathol. (2019). doi: 10.1177/0300985819843682. [Epub ahead of print].

39. Wick MJ. Living in the danger zone: innate immunity to Salmonella. Curr Opin Microbiol. (2004) 7:51-7. doi: 10.1016/j.mib.2003. 12.008

40. Badia R, Brufau MT, Guerrero-Zamora AM, Lizardo R, Dobrescu I, MartinVenegas $\mathrm{R}$, et al. beta-Galactomannan and Saccharomyces cerevisiae var. boulardii modulate the immune response against Salmonella enterica serovar Typhimurium in porcine intestinal epithelial and dendritic cells. Clin Vaccine Immunol. (2012) 19:368-76. doi: 10.1128/CVI.05532-11

41. Sweeney T, Collins CB, Reilly P, Pierce KM, Ryan M, O’Doherty JV. Effect of purified beta-glucans derived from Laminaria digitata, Laminaria hyperborea and Saccharomyces cerevisiae on piglet performance, selected bacterial populations, volatile fatty acids and pro-inflammatory cytokines in the gastrointestinal tract of pigs. Br J Nutr. (2012) 108:1226-34. doi: 10.1017/S0007114511006751

42. Spitzer F, Vahjen W, Pieper R, Martinez-Vallespin B, Zentek J. A standardised challenge model with an enterotoxigenic F4+ Escherichia coli strain in piglets assessing clinical traits and faecal shedding of fae and est-II toxin genes. Arch Anim Nutr. (2014) 68:448-59. doi: 10.1080/1745039x.2014.968701 
43. Rostagno $\mathrm{MH}$, Eicher SD, Lay DC. Immunological, physiological, and behavioral effects of salmonella enterica carriage and shedding in experimentally infected finishing pigs. Foodborne Path Dis. (2011) 8:623-30. doi: 10.1089/fpd.2010.0735

44. Colditz IG. Effects of the immune system on metabolism: implications for production and disease resistence in livestock. Livest Prod Sci. (2002) 75:25768. doi: 10.1016/S0301-6226(01)00320-7

45. Huntley NF, Nyachoti CM, Patience JF. Immune system stimulation increases nursery pig maintenance energy requirements. J Anim Sci. (2017) 95:68-9. doi: 10.2527/asasmw.2017.12.145

46. O’Neill LA, Kishton RJ, Rathmell J. A guide to immunometabolism for immunologists. Nat Rev Immunol. (2016) 16:553-65. doi: 10.1038/nri. 2016.70

47. Dubreuil P, Farmer C, Coutoure Y, Petitclerc D. Hematological and biochemical changes following an acute stress in control and somatostatinimmunized pigs. Can J Anim Sci. (1993) 73:241-52. doi: 10.4141/ cjas $93-026$
Conflict of Interest Statement: JRC was employed by Phileo Lesaffre Animal Care.

The remaining authors declare that the research was conducted in the absence of any commercial or financial relationships that could be construed as a potential conflict of interest.

This work is authored by Nicole C. Burdick Sanchez, Jeffery A. Carroll, Jimmie R. Corley, Paul R. Broadway and Todd R. Callaway on behalf of the U.S. Government and, as regards Dr. Burdick Sanchez, Dr. Carroll, Dr. Corley, Dr. Broadway, Dr. Callaway, and the U.S. Government, is not subject to copyright protection in the United States. Foreign and other copyrights may apply. This is an open-access article distributed under the terms of the Creative Commons Attribution License (CC BY). The use, distribution or reproduction in other forums is permitted, provided the original author(s) and the copyright owner(s) are credited and that the original publication in this journal is cited, in accordance with accepted academic practice. No use, distribution or reproduction is permitted which does not comply with these terms. 